\title{
Actualidad de lo sagrado. El espacio público como territorio de misión*
}

\author{
Manuel Delgado RuIZ \\ Universitat de Barcelona \\ Institut Català d'Antropologia
}

\begin{abstract}
$Y$ la gente se arrodilló y rezó, convirtiendo al neón en su dios. $Y$ el letrero emitió su mensaje con las palabras de que estaba formado. $Y$ el letrero decia : "Las palabras de los profetas están escritas en las paredes de los metros"
\end{abstract}

(Simon \& Garfunkel, "El sonido del silencio")

Sucedió que, yendo de camino, cuando estaba cerca de Damasco, de repente le rodeó una luz venida del cielo.

(Hechos de los Apóstoles, 9, 3)

\section{RELIGIONES DEL UMBRAL}

El panorama de ese ámbito exento en nuestras sociedades al que damos en llamar la religión viene definido, hoy, por la proliferación y la perceptibilidad creciente de corrientes minoritarias que se proclaman capaces de rescatar, a quienes se afilian a ellas, de un mundo dominado por el mal y la desesperación. Estas organizaciones religiosas aparecen como cuerpos extraños en sociedades que ya cuentan con tradiciones religiosas asentadas y son percibidas por el Estado, por la prensa y por las mayorías sociales como asociaciones perversas que amenazan la salud mental y la libertad de los ciudadanos. La imaginación mediática se refiere entonces a estos movimientos como "sectas destructivas", a las que se les depara un tratamiento hostil por no decir persecutorio en muchos casos. En tanto todos estos grupos suelen desarrollar un fuerte activismo proselitista y experimentan un proceso de crecimiento y expansión, las iglesias instituidas no

* Este trabajo que aparece incluido en El animal público (Barcelona: Anagrama, 1999. Premio Anagrama de Ensayo), se presentó en el CSIC (Madrid) el 12 de mayo de 1998, bajo el título: "La actualidad de lo sagrado (la religiosidad en tiempos de incertidumbre)", dentro del XVIII Curso de Etnología Española "Iulio Caro Baroja". 
dudan en adoptar los aspectos más atractivos de sus discursos, así como sus estrategias de apostolado duro. En su conjunto, todas estas corrientes pueden ser contempladas compitiendo en el libre mercado de sentidos de la vida, siendo el producto con que concurren el mismo: la salvación.

Sería viable resumir las características generales de estos movimientos de renovación religiosa. Digamos que tienen consciencia de ellos mismos y de la misión terrenal que - sostienen - han de llevar a cabo por mandato divino, siendo su formación y prácticas de reclutamiento procesos cỏnscientes y deliberados. A estas sectas o cultos se incorporan individuos que han experimentado una conversión, que puede ser súbita o paulatina, y que es vivida por los neófitos como un auténtico nuevo nacimiento. Quienes se incorporan a una de las corrientes heterodoxas o marginales en relación a las instituciones religiosas dominantes han sido considerados con méritos suficientes para ser aceptados en su seno, para luego pasar a considerarse a sí mismos como participantes de una élite, un grupo privilegiado que adopta el modelo bíblico del pueblo elegido de Israel. Los miembros de estos grupos se entregan al servicio de un proyecto de futuro que consideran justo y urgente. Su integración supone un acto de aceptación, con frecuencia exclusivista, o cuanto menos renuncia a importantes parcelas de autonomía personal. Suele detectarse en los nuevos movimientos religiosos la presencia de una justificación ideológica autolegitimadora, cosa lógica pensando en que todos ellos se autoatribuyen una autoridad sagrada a la hora de invitar a los humanos a abandonar una forma de vida considerada impura. También es habitual encontrar mecanismos de exclusión de desviados, que son resultado de la consciencia que el grupo tiene de su tarea y de la necesidad de mantener su integridad para llevarla a término. Este factor - hay que añadir - se ve agudizado por el aislamiento y el rechazo u hostilidad que sufren muy habitualmente este tipo de asociaciones. Cualquier amenaza desde la heterodoxia interior, la negligencia o un insuficiente compromiso pueden implicar la exclusión de algunos de sus miembros, considerados indignos. Por último, estas minorías religiosas suelen mantener una relación conflictiva con las iglesias homologadas y con los cultos hegemónicos en el contexto socio-histórico en que se mueven.

Los miembros de los nuevos movimientos religiosos se consideran reformadores de la fe y de la práctica religiosa. Estas corrientes son, en todos los casos, salvadoras, en tanto implican fórmulas para protegerse o escapar de un mundo que se percibe como un imperio del pecado, que se debe cambiar o del que urge escapar o defenderse. De una forma u otra todas son milenaristas y escatológicas, en tanto presumen un final más o menos inmediato de los tiempos, tal y como los inquietantes signos del presente anuncian. Es frecuente que renuncien de la organización eclesial, y en cualquier caso descalifican el ritualismo en favor de 
una fe de tipo privado y una experiencia intensa de lo inefable. Esto último no es incompatible con la comunión litúrgica con el grupo de escogidos, con la aceptación de liderazgos carismáticos o con la lealtad a las enseñanzas de un maestro fundador.

Esta intensificación del activismo religioso no se corresponde con una recuperación en el prestigio de las grandes iglesias tradicionales, ni suele implicar, salvo excepciones, grandes movilizaciones de masas. Se concreta en pequeños grupos extremadamente activos, cuya influencia creciente parece dar la razón a quienes están convencidos de que la actividad de grupos muy pequeños e incluso de individuos marginados puede tener una incidencia en los procesos de cambio mucho mayor de la que pueden obtener instancias ideológicas que cuentan con medios masivos a través de los cuales amplificar sus mensajes. El primero en apreciar este tipo de fenómenos fue, a finales del pasado siglo, Gabriel Tarde, que vio cómo los cambios estratégicos en los estados de ánimo colectivos podían resultar de la aparición de factores nuevos ajenos, en principio, al orden social dominante, representados muchas veces por elementos periféricos o muy minoritarios - hasta microscópicos- dentro del sistema global ${ }^{1}$. El efecto no era muy distinto del que mucho después estudiarían los especialistas en sistemas complejos, al observar ese momento en que una determinada estructura macroscópica empieza a perder estabilidad a partir de microscópicas perturbaciones o fluctuaciones de carácter local. En el texto más emblemático de la divulgación de la teoría del caos, La nueva alianza, Ilya Prigogine e Isabelle Stengers reconocían cómo "grupos pequeños, aislados o incluso perseguidos por el resto de la sociedad, pueden ser el origen de algunas de las innovaciones que han transformado la sociedad. Grupos minoritarios que ocupan una posición marginal con respecto a los cauces dominantes han tenido un destacado poder innovador en la historia" ${ }^{2}$. Esta idea es la que permitiría contemplar los nuevos movimientos religiosos a la manera de lo que, desde distintos esquemas conceptuales, se ha llamado "mutas" o "manadas" (Canetti), "tribus" (Maffesoli) o "rizomas" (Deleuze y Guattari), para definir pequeños grupos que se organizan y expanden por agitación, siguiendo movimientos policentrados y diagramáticos.

En cuanto al sentido que cabe atribuir a estas corrientes irregulares de culto, podría ser el de garantizar un conjunto de eficacias psicológicas y sociales, la mayoría compartidas con otros activismos de libre adscripción con objetivos mundanos, políticos o civiles. Proveen de una estruc-

1 Cf. Gabriel TARDE, Les lois sociales (París: Félix Alcan, 1921), pp. 15-16.

2. Ilya PRIGOgIne e Isabelle STENGERS, La mueva alianza. Metamorfosis de la ciencia (Madrid: Alianza, 1990), p. 220. 
tura de plausibilidad, capaz de ordenar jerárquicamente los significados y ofrecer modelos cognitivos poderosos. Dotan de una comunidad de referencia, organizada con claridad, que sirve de ámbito desde el que protegerse o purificarse de las contaminaciones procedentes de un mundo percibido como en proceso de putrefacción. Fomentan doctrinalmente la convicción de que la sociedad puede y debe ver mitigada o incluso redimida su postración actual, por medio de intervenciones que modifican la consciencia colectiva o personal, lo que justifica un permanente estado de agitación propagandística y de reclutamiento. También permiten marcos en los que instalar individuos o grupos mal o precariamente integrados, con dificultades a la hora de encontrar su lugar en la sociedad, contribuyendo así a que nadie escape de la necesidad que experimenta el orden socio-político actual de mantener a todos sus miembros permanentemente encuadrados y movilizados. Facilitan la articulación de identidades individuales sólidas, substituyendo o complementando formas primarias de socialización que se han mostrado insuficientes para disminuir $\mathrm{O}$ aliviar los sentimientos de aislamiento y atomización. Por último, brindan un código moral claro, susceptible de orientar las conductas y de regular de manera positiva la urdimbre de las interacciones humanas.

Todas esas virtudes están directamente relacionadas con el tipo de función que cumplen las afinidades voluntarias hoy por hoy, que es básicamente la de hacer frente a las tendencias a la anomia y a la desestructuración que amenazan a individuos inmersos en procesos de urbanización y modernización, procesos en los que las referencias colectivas en todos los niveles - política, familia, moral, religión, etc.- aparecen desacreditadas e incapaces de otorgar significado a la experiencia crónicamente desorientada de un mundo en constante cambio. En todos los casos es fácil ver a estos movimientos constituyéndose en mecanismos de enlace o mediación entre los sujetos y una cada vez más débil e insuficiente dimensión comunitaria, de ahí que hayan sido descritos como "estructuras de mediación". El servicio que estas corrientes de adscripción voluntaria prestan se produce en un doble sentido, sólo en apariencia paradójico. Por una parte ofrecen satisfacción a esa necesidad de una pertenencia comunitaria, una hermandad capaz de hacer frente a la soledad a que tantas veces aboca la vida en contextos urbanizados. Pero al mismo tiempo estos grupos, en la medida en que en todos los casos se fundan en una intensa vivencia privada de los ideales compartidos, también están en condiciones de organizar una coherencia identitaria personal que el individuo no siempre habrá sabido encontrar en una vida ordinaria carente de proyectos fundamentales.

Esta situación es parecida a la que se ha descrito, desde presupuestos 
neodurkheimianos, como crisis o ausencia de cuadrículas fuertes ${ }^{3}$ o códigos restringidos ${ }^{4}$. Se alude en ambos casos al déficit de pautas poderosas y de prestigio que permitan interiorizar el esquema de papeles sociales y al fracaso de los mecanismos de control mediante los que cada sociedad ejerce su autoridad y exige obediencia. Estos términos se opondrían, respectivamente, a las cuadrículas débiles y a los códigos elaborados, característicos de sociedades modernizadas, en las que los individuos estarían poco menos que obligados a elegir entre una amplia oferta de opciones morales disponibles en cada momento. Se trataría, como se ve, de una manifestación más de aquello que Erich Fromm había llamado "miedo a la libertad". Bien podríamos decir, para resumir, que la incorporación a una asociación con una interpretación congruente y un plan de acción sobre el mundo funciona como una estrategia que evita o mantiene a raya la posibilidad de una desarticulación total de la personalidad y de la identidad.

\section{SECTAS RELIGIOSAS Y SOCIEDADES INTERSTICIALES}

Colocar la explicación del creciente éxito de las corrientes de innovación religiosa como uno más de los síntomas que acompañan, hoy como ayer, el proceso de modernización, precisamente como una estrategia adaptativa al servicio de comunidades e individuos con problemas de articulación social o psicológica, nos advierte de la similitud de este tipo de fenómenos de adscripción intermediadora con lo que los teóricos de la Escuela de Chicago denominaron en los años 20 sociedades intersticiales, organizaciones sociales que se instalaban en zonas de nadie y que se constituían entre las distintas regiones sociales y morales de la ciudad, colonizando los amplios espacios desterritorializados - tanto morales como físicos - que se extendían a lo largo y ancho de la nueva vida social urbana $^{5}$. La noción de sociedad intersticial ha venido sirviendo desde su acuñación para analizar las microsociedades y las microculturas juveniles - de las bandas juveniles en las grandes aglomeraciones industriales norteamericanas a principios de siglo a las actuales "tribus urbanas"-, a las

3 Mary Douglas, Símbolos naturales (Madrid: Alianza, 1988), pp. 73-89.

4 Basil BERNSTEIN, "Códigos elaborados y restringidos: sus orígenes sociales y consecuencias", A. G. Smith (ed.), Cultura y comunicación (Buenos Aires: Nueva Visión, 1977), pp. 45-66.

5 El término aparece por primera vez en F. M. Trasher, The Gang. A Study of 1313 gangs in Chicago (Chicago: University of Chicago Press, 1963 [1926]), y en C. R. SHAw y H. MCKAY, Juvenile Delinquency and Urban Areas (Chicago: Universty of Chicago Press, 1969 [1927]). 
que se atribuía un papel complementario o paralelo respecto de unas instituciones sociales primarias que distaban mucho de lograr vertebrar sociedades como las modernas, con una tendencia irrefrenable a la discordancia y a la inestabilidad. De este modo, las sociedades intersticiales tratarían de cubrir los territorios físicos y morales que la estructura social dominante dejaba al descubierto, restaurando fracturas en el continuum social, cubriendo "agujeros negros" de la trama social, sirviendo de avanzadilla o de sucedáneo, según los casos, a dinámicas de cristalización social más complejas. Puentes sobre aguas turbulentas.

Desde la antropología social de extracción estructural-funcionalista, Eric R. Wolf retomó la noción de intersticialidad para referirse a instancias informales que complementaban sistemas institucionales deficientes. Tales estructuras interpersonales suplementarias o paralelas - "grupos que se adhieren a la estructuras institucionales como los moluscos al casco de un barco herrumboso" ${ }^{6}$ - se superponen al sistema institucional y existen en virtud suya, muchas veces con funciones análogas a las que en las sociedades tradicionales jugaban las relaciones de parentesco. No es ya que esas estructuras sociales de intervalo no constituyan ninguna amenaza para el orden establecido - por mucho que su aspecto extraño pueda acarrearles mala reputación y convertirlas en diana de todo tipo de desconfianzas y ataques-, sino que constituyen la garantía del buen metabolismo del marco institucional formal en sociedades complejas. Ulf Hannerz se ha referido a este tipo de neoestructuras sociales "como mecanismos básicamente defensivos mediante los cuales las personas tratan de parar los golpes que reciben de una disposición social que no pueden controlar" ${ }^{7}$. Insistiendo en esa función protésica de los nuevos cultos, Georges Bataille ya había llegado a parecida conclusión en 1938, cuando, en una discusión con Roger Caillois a propósito de las sectas y las sociedades secretas, sentenciaba que "comunidad electiva [...] es un tipo de organización secundaria con carácteres constantes y a la que siempre se puede recurrir cuando la organización primaria de la sociedad no puede satisfacer ya todas las aspiraciones que surgen" 8 .

Esa lectura en clave de intersticialidad da por supuesto que las nuevas organizaciones religiosas no tienen como función oponerse a una

6 Eric R. Wolf, "Relaciones de parentesco, de amistad y de patronazgo en las sociedades complejas", en M. Banton (comp.), Antropología social de las sociedades complejas (Madrid: Alianza, 1990), p. 20.

7 Ulf Hannerz, Exploración de la ciudad (México: FCE, 1986), p. 309.

8 Comentarios de Georges Batallle a Roger Caillois, "Cofradías, órdenes, sociedades secretas, iglesias", D. Hollier (ed.), El Colegio de Sociología (Madrid: Taurus, 1982), p. 179. 
determinada estructura social, sino precisamente a su ausencia o a sus déficits. No compiten con una visión del mundo hegemónica, sino con el hecho de que no exista ninguna visión del mundo capaz de ejercer su autoridad desde el prestigio. No se enfrentan a la legitimidad existente, sino a la deslegitimidad de lo dado. No se rebelan contra las instituciones que dan sentido a la sociedad, sino contra que la sociedad no sea capaz de dar a luz instituciones capaces de otorgarle un sentido. La alternativa que enarbolan no se levanta ante una cierta definición de lo real, sino como alternativa a la indefinición que parece afectar crónicamente a lo real. Su enemigo a batir no son las certezas dominantes, sino el dominio absoluto de las incertezas. No están en contra de un universo simbólico articulado, sino contra un mundo del que los significados parecen haber huido en desbandada. No son alteridades, puesto que existen y actúan contra la alteridad generalizada que representa la experiencia de la modernidad. Es al avance de lo inorgánico a lo que ofrecen resistencia, como consecuencia de una añoranza masiva de la organicidad.

Por ello sorprende que se haya insistido en señalar a las nuevas corrientes religiosas como ejemplos de communitas, en el sentido que Victor Turner le daba a esa voluntad de constituir opciones de vida colectiva basadas en la a-estructuración, la indiferenciación y la carencia de referentes que caracterizaría la fase liminal en los rites de passage, es decir la secuencia de indeterminación que los iniciados viven entre la separación y la reintregación en los tránsitos de un status social a otro ${ }^{9}$. El propio Turner proponía diferentes tipos actuales de adscripción voluntaria -aaronitas disidentes del mormonismo, hippies, ángeles del infierno-, como ejemplos de "movimientos liminales contemporáneos" ${ }^{10}$. Con ello, Turner se apartaba del energicismo social de Émile Durkheim y de Arnold Van Gennep, del que inicialmente bebía su teoría sobre liminalidad y communitas, para identificar esta última, sin explicitarlo, con la Gemeinschaft, la comunidad homogénea y naturalizada que Ferdinand Tönnies oponía a la Gesellschaft o "asociación", y que representaba las virtudes de la comunión prístina y vital fundada en el mero calor humano, la communio totius vitae. En verdad que el concepto de Tönnies de comunidad apenas debería tener que ver con la communitas, entendiendo esta última como el vínculo que se produce entre los neófitos en las situaciones de liminalidad. "La comunidad —escribe Tönnies- debería ser entendida como organis-

9 Cf. Arnold VAN GENNEP, Los ritos de paso (Madrid: Taurus, 1984), y V. TURnER, "Ni lo uno ni lo otro. La fase liminal en los ritos de paso", La selva de los símbolos (Madrid: Siglo XXI, 1991), pp. 103-123.

10 Victor TURNer, El proceso ritual (Madrid: Taurus, 1982), pp. 195 y ss. 
mo vivo y la asociación como un artefacto, un agregado mecánico [...] [Los individuos] en la comunidad permanecen unidos a despecho de todos los factores que tienden a separarlos, mientran que en la Gesellschaft se mantienen esencialmente separados a pesar de que todos los factores tienden a su unificación" "11. Si la liminalidad representa un máximo de inorgacidad, la Gemeinschaft es precisamente lo contrario, la expresión de "vida orgánica y real", que se opone a la "estructura imaginaria y mecánica" de la Gesellschaft, la asociación o forma social propia de la sociedad modernizada. En ese sentido, la Gemeinschaft se podría identificar con lo que luego Robert Redfield llamará "sociedad folk", al tiempo que se emparentaría con la "sociedad mecánica" en Durkheim. Frente a esa visión que, partiendo del propio Turner, tipifica los nuevos cultos religiosos como construcciones en communitas, más bien deberíamos reconocer que es contra la communitas generalizada — "todo lo sólido se desvanece en el aire", como reza el título del famoso libro de Marshall Berman-, que representa la experiencia de la modernidad, que estos grupos se revelan, puesto que no aspiran a derrocar la estructura social existente, sino a rebatir la imposibilidad de organizar pautas capaces de dotar de seguridad, homogeneidad y equilibrio moral la existencia en las sociedades urbano-industriales.

De hecho, habría muchos otros lugares de la vida contemporánea donde poder dar con la inestabilidad autoorganizada que caracterizaría las liminalidades y las communitas. Estas las encontraríamos mucho más, por ejemplo, en la forma como se ha descrito la actuación de las muchedumbres urbanas (Canetti, Mafessoli) o las filigranas de apariencia absurda a que se abandonan los viandantes que usan el espacio público (De Certau, Joseph). Al tiempo, pocas cosas más parecidas a la indefinición de la liminalidad ritual que las descripciones que se har hecho de los no-lugares, concepto acuñado por Michel de Certau ${ }^{12}$ para aludir a espacios generados por la urbanidad moderna y que constituyen la negación del lugar, o lugar que se ha esfumado para dar paso a la pura posibilidad de lugar, espacio todo él frontera. Marc Augé identifica esos no-lugares con las estaciones, las superficies comerciales, los aeropuertos, los medios de transporte: aespacios donde ni la identidad ni la relación ni la historia tienen verdadero sentido, donde la soledad se experimenta como exceso o vaciamiento de la individualidad, donde sólo el movimiento de las imáge-

11 Ferdinand TÖNNIES, Comunitat $i$ associació (Barcelona: Edicions 62/La Caixa, 1984), p. 72.

12 Cf. Michel DE CERTAU, L'invention du quotidien. 1. Arts de faire (París: Gallimard, 1992). 
nes deja entrever borrosamente por momentos, a aquel que las mira desaparecer, la hipótesis de un pasado y la posibilidad de un porvenir" ${ }^{13}$. La diferencia entre la communitas y la estructura se parecería a la que le sirviera a Baudelaire para definir lo moderno como lo efímero, lo fugaz, lo contingente, "esa mitad del arte cuya otra mitad es lo eterno y lo inmutable" ${ }^{14}$. Es decir: modernidad igual a liminalidad en proceso de metástasis, en un cuerpo social cada vez menos orgánico. Sería mucho más propio reconocer que los nuevos cultos se justifican como reacción de protección y defensa ante esa fuente general de peligro y contaminación que representa una sociedad que ha desertizado moralmente grandes extensiones de su territorio y que parece dominada por las inconsistencias y los tránsitos, es decir por cuadros de liminalidad-communitas.

Victor Turner define la oposición "estructura versus communitas" como idéntica a la de "estados versus transiciones" y, precisamente por eso, la experiencia del espacio público, la urbanidad entendida como el interminable trabajo de la sociedad urbana sobre sí misma, es, por definición casi, un ejemplo de liminalidad o communitas permanente. El propio Turner apunta que "la communitas surge allí donde no hay estructura social" ${ }^{15}$, es decir dónde lo que hay es ausencia, carencia o al menos grave debilidad de lo orgánico social. Pero eso no se corresponde con los ejemplos que él mismo propone -aaronitas, hippies, ángeles del infierno-, que, como hemos visto, deberían pasar mucho más como estructuras intersticiales, cuya función es compensar una ausencia de estructura. Son, por tanto, movimientos anti-liminales. En la secta -al igual que ocurre en otras sociedades-intervalo como las llamadas "tribus urbanas" - lo que se dan son formas elementales, al tiempo frágiles y acaso por ello severas, de institucionalización, de jerarquización, de segmentarización, etc., que contrarrestan o alivian situaciones de desegmentación, de desjerarquización y de desinstitucionalización. Por tanto, no es que los sectarios sean ugentes del umbral", es decir habitantes crónicos de un cuadro de liminalidad, sino que están pretendiendo ponerse a salvo de la intemperie estructural a que les somete la vida moderna, ella sí, toda hecha de umbrales.

Si en algún aspecto debería percibirse con especial claridad cómo las nuevas denominaciones religiosas asumen la tarea de ocupar estructuralmente zonas no tanto desorganizadas como en un continuo e intermina-

13 Marc Augé, Los no-lugares. Espacios del anonimato (Barcelona: Gedisa, 1993), p. 92.

14 Cf. Charles Baudelaire, El pintor de la vida moderna (Murcia: Colegio de Aparejadores y Arquitectos Técnicos, 1995).

15 TURNER, El proceso ritual, p. 132. 
ble proceso de organización, este podría ser el de las relaciones que muchos de estos grupos mantienen con el espacio público, aspecto que se contemplará a continuación.

\section{UN ESPACIO SIN DIOS}

Los procesos de secularización que acompañaron la incorporación de las distintas sociedades a la modernidad —estatalización, homogeneización cultural, industrialización, urbanización, etc.- consistieron, en gran medida, en el sistemático desmantelamiento de los instrumentos tradicionales de control social, en favor siempre de una vivencia interior de la trascendencia. En ese sentido, no es erróneo afirmar que secularización es subjetivización de la experiencia religiosa, como requisito insoslayable del individualismo; ese sistema jurídico-filosófico propio de las sociedades modernizadas que coloca al individuo psicofísico como fundamento y fin de todas las relaciones morales y políticas y que funda la concepción moderna de ciudadano. La religión se identifica del todo con la "experiencia del corazón", es decir subsiste sólo acuartelada en la vivencia íntima. En el plano de lo público, se entiende que es indispensable que la religión se limite a una retórica o quede restringida a un conjunto de operaciones simbólico-conmemorativas, es decir no eficaces. Como ha hecho notar Harvey Cox, tal fenómeno se traducía en un principio según el cual "cuanto mayor era la importancia del rol de la religión en el sector público, se afirmaba, peores eran las condiciones para que el proceso de modernización siguiera su curso" ${ }^{16}$. A su vez, todo ello lleva pareja una destrascendentalización del tiempo y del espacio, en particular del tiempo y del espacio públicos, respecto de los cuales las viejas instituciones religiosas reciben la casi explícita prohibición de intervenir normativizadamente, como hasta entonces ${ }^{17}$. Por plantearlo como sugería Thomas Luckmann, "las instituciones sociales han "emigrado" del cosmos sagrado" ${ }^{18}$, en la medida en que se ha producido una distancia crítica entre la autonomía subjetiva de los individuos —objeto de una auténtica santificación-

16 Harvey Cox, "Religión y política en Europa: Los nuevos debates sobre los dominios de lo secular/sagrado, y de lo público/secular, Historia y fuente oral, 10 (1993), p. 31.

17 Cf. Jean REMY, "Villes, espaces publics et religions: récits d'espérance et pratiques quotidiennes", Social Compass, XL, 1 (1998), pp. 23-42.

18 Thomas LuCKMAnN, La religión invisible (Salamanca: Sígueme, 1973), p. 128. 
y la autonomía objetiva de las esferas sociales institucionalizadas, percibidas ahora como inhumanas, racionales, frías, etc.

No se debe confundir esa desabsolutización del tiempo y el espacio sociales -legible en términos de descristianización- como una desacralización. Lo sagrado no ha desaparecido de las realidades externas con los procesos de secularización y estamos lejos de haber visto cumplido el pronóstico weberiano sobre el "desencantamiento del mundo". Como ha hecho notar José Luis Anta, "es el mundo civil el que se ha apropiado de los universos simbólicos de la religión" ${ }^{19}$. En efecto, bien podríamos afirmar que, una vez completado el repligue de lo religioso explícito, el ámbito público se vio enseguida saturado por formas implícitas, no trascendentes y superficiales de sacralidad, sacralidades glaúcicas, por así decirlo, provistas por las puestas en escena de las nuevas liturgias mundanas de la política, el deporte o el show-bussines, o por los reclamos de la publicidad, la moda y del consumo de masas. En cierto sentido el consumismo y los mass media han situado nuestras sociedades en unos niveles de fetichización y de paganización casi insólitos. Más bien cabría decir que de lo que el espacio público de las sociedades urbanizadas había quedado vacante era de lo que Peter L. Berger hubiera llamado una "simbólica bóveda protectora" ${ }^{20}$, es decir de fuentes verdaderamente totalizadoras que legitimaran e hicieran subjetivamente significativas las prácticas sociales y las vivencias cotidianas. Los individuos debían buscar la presencia de lo trascendente fuera de un mundo fáctico en que ya nada iba a continuar siendo autoevidente ni dado por supuesto: debía darse con la realidad profunda de la vida en y sólo en la propia subjetividad.

Todo ese proceso pasaba por establecer que la inmanencia de Dios sólo podía ser percibida a través de la experiencia íntima, al tiempo que se consideraba blasfema toda pretensión de que el mundo pudiera servir como soporte o medio para la expresión de lo trascendente. En ese sentido cabía sostener que las políticas y las violencias modernas contra la extroversión de lo divino consistieron en actuaciones relativas al espacio; es decir, iniciativas que pretendieron incidir sobre ciertos lugares, sonidos, trayectos y otros aspectos del paisaje que eran considerados como víctimas de la sacrílega pretensión de que la naturaleza podía expresar la

\footnotetext{
19 José Luis ANTA FÉlEZ, "Magia y religión en el universo contemporáneo: Una aproximación antropológican, J. Latorre García y J.C. Sánchez-León (eds.), Magia y religión en la bistoria (Jaén: UNED, Centro Asociado Andrés de Vandelvira, 1997), p. 129.

20 Peter L. BERGER, Para una teoría sociológica de la religión (Barcelona: Kairós, 1981), p. 214.
} 
presencia de lo inefable. En eso consistieron las legislaciones anticlericales y los movimientos de destrucción iconoclasta que acompañaron las transformaciones modernizadoras ${ }^{21}$. Esa lógica casi topofóbica del gran proyecto reformador en materia religiosa se empeñó en desactivar todas aquellas formalizaciones cualitativas del espacio —edificios religiosos, procesiones, cruces, sonidos de campanas, etc.- que expresaban los valores culturales que estaban organizando el mundo social. Se trataba, en cierto modo, de renunciar a las prácticas destinadas a definir significativamente el suelo, de una neutralización del espacio y del tiempo que no permitiera encontrar en ellos jerarquías, ni referentes transmundanos. Esa desterritorialización sistemática consistió, en el plano simbólico, en desalojar a Dios del tiempo y del espacio. El poder de Dios ya no sería un poder geográfico, como tampoco sería un poder cronológico. Dios actúa en y sobre el espacio y el tiempo, pero no está, no puede estar ni en el espacio ni en el tiempo, sino sólo dentro de cada cual ${ }^{22}$. Por principio, el espacio y el tiempo pertenecen, en el dualismo cartesiano y en la teología protestante, al campo categorial de lo exterior, asociado al cuerpo, a la materia, es decir a aquellas vías por las que lo único sobrehumano que podría manifestarse serían potencias malignas.

A partir de ese momento, el espacio público - puesto que es mundo y parafraseando a Lutero- queda bajo el dominio del Demonio y su control, o lo que es igual, su territorialización, debe corresponder al Estado civil, la única salvaguarda que la debilidad humana encuentra frente a Satanás y frente a sus propias inclinaciones antisociales. La secularización es entonces politización del espacio, en el sentido de que las comunidades locales se ven desposeídas por la violencia de su dominio espacial, que ejercían a través de la territorialización sacramental llevada a cabo desde los lugares y las deambulaciones rituales. El paisaje pasaba así a quedar sometido a las lógicas de organización y fiscalización territorial ejecutadas ya no desde el poder divino, es decir desde las propias comunidades reificadas y objetivadas, sino desde el poder estatal, el Leviatán

21 Cf. Manuel Delgado RuIz, "Anticlericalismo, espacio y poder. La destrucción de los rituales católicos en España, 1931-1939", Ayer, 27 (1997), pp. 150-180.

22 Este axioma ha sido asumido desde las tendencias más experiencialistas del propio catolicismo. Los pentecostalistas de obediencia romana, seguidores de Renovación Carismática, se reunen en un lugar "cualquiera" - casa particular, sacristía, local comercial-, cuya sobredeterminación como "Sagrado" viene dada, no por una consagración ritual objetiva, como ocurre con los templos, sino por la presencia misma del grupo, él mismo fuente subjetiva de sacramentalidad topológica. Cf. Albert DouTRELOUX y Colette DEGIVE, "Perspective anthropologique sur un mouvement religieux actuel", Social Compass, XXV, 1 (1978), pp. 43-54. 
hobessiano a cuyo gobierno un mundo destrascendentalizado debía someterse.

Desde tal perspectiva, la calle, como expresión más representativa de ese nuevo espacio público que la modernidad funda, pasa a concebirse como exponente máximo también de los peligros de la desestructuración, o cuanto menos de toda fuente trascendente de organización de la vida social. Todas las percepciones negativas de la calle tienen que ver con ese supuesto de malignidad que afecta a unas ciudades sin Dios, escenario de todo tipo de peligros para el alma, en las que los viandantes podían ser pensados como sonámbulos sin espíritu, naúfragos interiores a merced de mil peligros, todos ellos asociados precisamente a la liminalidad, es decir a la actividad "en hueco", a-estructurada, estocástica, que tenía lugar en su seno. La calle era, en las sociedades modernas, el teatro de los delirios de masas, de los circuitos irracionales de muchedumbres desorientadas, de la incomunicación, de la indiferencia...

Ya en el xIX Charles Baudelaire, acaso el primer teórico de la especificidad de lo urbano, reconocía sentirse asfixiado y desconcertado por las multitudes. Los pioneros de la psicología social de masas francesa de finales del siglo pasado (Le Bon, Tarde) advertían, a su vez, cómo en la ciudad se desvelaba la naturaleza histérica y criminal de las multitudes. Idénticas impresiones encontramos en la primera sociología alemana. Georg Simmel había puesto el acento en "la nerviosidad" de las ciudades, aceleramiento o crispación perceptual, consecuencia de "la violencia de la gran ciudad", que obliga a una "reserva" cuyo sentido último "no es sólo la indiferencia, sino [...] una silenciosa aversión, una extranjería y repulsión mutua, que en el mismo instante de un contacto más cercano provocado de algún modo, redundaría inmediatamente en odio y lucha” ${ }^{23}$. Algo parecido podría decirse de Ferdinand Tönnies, cuya aludida noción de Gemeinschaft se inspiraba en el modelo de la estructura social transparente y significativa atribuida a las "gentes del campo", basada en relaciones personales de intimidad y confianza, vínculos corporativos y colectivos, relaciones de intercambio, sistema divino de sanciones, etc., opuesta a la Gesellschaft, hecha de relaciones impersonales entre desconocidos y característica de la vida en la metrópolis. Al contrario de lo que supone Victor Turner, identificando la communitas liminal con la Gemeinschaft, es esta última la que se corresponde con la idea de estructura social clara, mientras que es la Gesellschaft la que se asimila en Tönnies a una "Vida pública" altamente impredecible e inconsistente: "Allí donde la cultu-

23 Georg Simmel, "Las grandes urbes y la vida del espíritu", El individuo y la libertad (Barcelona: Península,1986), p. 253. 
ra urbana florezca y fructifique, aparecerá la "asociación" como órgano indispensable... En oposición a la Gemeinschaft (comunidad), la Gesellschaft (asociación) es transitoria y superficial” ${ }^{24}$.

Tönnies pertenece a esa misma corriente radicalmente antiurbana y nostálgica del mundo agrario que vemos recorrer el pensamiento reaccionario alemán —Riehl, Heiddeger, Jünger, Adenauer-y que tiene en Oswald Spengler uno de sus más conspícuos representantes. En el apocalíptico La decadencia de Occidente podemos leer:

El coloso pétreo de la ciudad mundial señala el término del ciclo vital de toda gran cultura. El hombre culto, cuya alma plasmó antaño el campo, cae prisionero de su propia creación, la ciudad, y se convierte entonces en su criatura, en su órgano ejecutor y, finalmente, en su víctima. Esa masa de piedra es la ciudad absoluta. Su imagen, tal y como se dibuja con grandiosa belleza en el mundo luminoso de los ojos humanos, contiene todo el simbolismo sublime de la muerte, de lo definitivamente "pretériton. La piedra perespiritualizada de los edificios góticos ha llegado a convertirse, en el curso de una historia estilística de mil años, en el material inánime de este demoníaco desierto de adoquines ${ }^{25}$.

En esa misma línea, los primeros estudios sociales de la ciudad, en tantos sentidos deudores de Simmel y Spengler, empezaron viendo en las calles el marco de una sociabilidad casi animal, una convivencia subsocial, como correspondía a una etología urbana derivada del darwinismo social. Para los teóricos de Chicago, el orden moral de la ciudad consistía precisamente en la carencia de todo orden moral, cosa previsible en un dominio de las segmentaciones, del desorden, donde la "vida interior" debía conocer dificultades inmensas para desarrollase, si es que lo conseguía. Un lugar "sin alma" - por decirlo como Louis Wirth en su célebre ensayo sobre la vida en las ciudades ${ }^{26}$-, donde el crimen y la locura acechaban y donde cada cual apenas si era poco más que su propia piel. La gran urbe era así contemplada como el espacio de la vacuidad de lo cotidiano, escenario donde sentir el desolador vacío de Dios, el abandono a la desorientación y al pecado. La ciudad, "víctima propiciatoria del tribunal del castigo divino enclavado en el templo expiatorio de la naturaleza" ${ }^{27}$. Para Erving Goffman y los interaccionistas la vida pública era el escena-

24 TÖNNIES, op. cit., p. 35.

25 Oswald Spengler, La decadencia de Occidente (Madrid: Revista de Occidente, 1966), vol. II, pp. 122-123.

26 Louis WIRTH, "El urbanismo como forma de vida", M. Fernández- Martorell (ed.), Leer la ciudad (Barcelona: Icaria, 1988), pp. 29-53.

27 Reinhard BENTMANN y Michel MülLER, La villa como arquitectura del poder (Barcelona: Barral, 1975), p. 191. 
rio de relaciones de poder fundadas en la inautenticidad y el simulacro, jurisdicción absoluta de la mentira. Richard Sennet nos ha enseñado cómo, a partir del siglo pasado, coincidiendo con la generalización del actual denominacionismo religioso, el espacio público se percibe como el territorio de las indeterminaciones morales, en que nadie puede aspirar a realizar su propia autenticidad y los demás constituyen siempre un peligro, y donde solo en la esfera privada de la vida íntima o, a lo sumo, del hogar familiar, podía aspirarse a una vivencia de la propia verdad natural:

Una multitud de desconocidos que pasean por las calles, que conversan, que hacen sus compras, que van o vienen del trabajo, aparece unida en la telaraña de la rutina; esta vida en común es inferior a la vida real que acontece dentro de cada una de las personas que componen la muchedumbre. Tal oposición delata esa enfermedad del alma que es el aburrimiento...: ahí fuera no hay nada que sea digno de mí $^{28}$.

Pero no se trata sólo de sugerir que los nuevos cultos sean reacciones de defensa y resistencia frente a un mundo cada vez más hostil y desalmado. No es caso de contemplarlos únicamente como expresiones adaptativas a un mundo indeseable, que exige formas de verdad —es decir, de simplificación plausible- que enfrentar a una tendencia creciente a la heterogeneización y la complejidad. Cabría más bien decir que ese rechazo del espacio público y el consiguiente repliegue hacia lo privado y lo íntimo estuvieron en la base misma de la concepción ortogonal de las ciudades modernas norteamericanas, esquemas abstractos y hiperracionalistas, un concepto que interpretó el espacio a construir como un desierto, en tanto la ciudad que se construye en América es, ciertamente, un páramo sin confines ni marcas, un ámbito de la agresividad o, como mucho, de la más atroz de las indiferencias hacia la suerte ajena ${ }^{29}$.

La expansión de las ciudades norteamericanas siguió el mismo criterio que orientara la expansión hacia el Oeste, que consistió no tanto en colonizar la diferencia, someter lo que les era ajeno - en este caso, los indios-, sino sencillamente en suprimirlo, derogar su existencia. Sorprende ver cómo la perspicacia descriptiva que el capitán Richard F. Burton tan bien supo aplicar a los paisajes culturales del África negra o del Oriente Próximo encontró su expresión también en su itinerario a través de las Praderas y hasta Utah, el país mormón, cuya capital ya se le antojó para-

28 Richard SENNET, La conciencia del ojo (Madrid: Visor, 1991), p. 152.

29 Cf. Richard SENNET, "Las ciudades norteamericanas: planta ortogonal y ética protestante", Revista Internacional de Ciencias Sociales, 12 (septiembre 1990), pp. 281-299. 
digma de lo que serían las urbes modernas en Estados Unidos y luego en todo Occidente. Refiriéndose a Salt Lake City, escribía a principios de la década de 1860:

El plano de la ciudad santa es el mismo que el de todas las ciudades del nuevo mundo, desde Washington hasta la futura metrópoli del continente australiano, un conjunto de calles anchas y alineadas, de pasajes, sendas y bulevares cortados en ángulos rectos. Vénse aquí en toda su amplitud los beneficios e inconvenientes del sistema rectangular; yo, por mi parte creo que este es perfectamente adaptable al nuevo mundo, así como el viejo estilo es obligatorio en Europa, bien que París parece convertirse al nuevo desde hace algunos años ${ }^{30}$.

A hacer notar cómo toda la colonización del Far West se llevó a cabo bajo la forma de una colosal communitas en marcha, y así lo constatan no pocas descripciones para las que la expansión hacia el Oeste fue una

verdadera épica lograda a través de integraciones y desintegraciones humanas, sociales y económicas, rápidas, contradictorias y sucesivas, pero siempre realizadas en proceso ascendente y con un material humano que tenía del conquistador el empuje, del aventurero su falta de escrúpulos, del pionero la confianza en sus propias fuerzas y del misionero su pathos religioso [...] Una masa humana fresca, capital naciente y agresivo, iniciativa incansable y arremetedora, carencia de formas y estructuras sociales previas y completa descentralización política señalaron ese instante de expansión de fuerzas creativas de donde ha manado por una centuria el mito de la unlimited America ${ }^{31}$.

De hecho, el puritano americano se sintió impulsado a la búsqueda de tierras vírgenes, espacios inocentes a los que poder "huir de todon, como forma radical de negación de la complejidad y como requisito para obtener un mayor autodominio. Es en esos espacios, como veremos ensegui$\mathrm{da}$, donde se desarrolla el germen de una forma de misionerismo adapta-

30 Richard F. Burton, Viaje a la ciudad de lo santos (Barcelona: Laertes, 1986), p. 34 .

31 A. Mendoza, Fuentes del pensamiento de los Estados Unidos (México: El Colegio de México, 1950), p. 155. Si hubiera que escoger un género cinematográfico que resumiera la naturaleza fronteriza, sin límites, de la experiencia urbana este sería, sin duda, el western, cuyos protagonistas encarnan a la perfección lo liminal, lo transitivo de la vivencia de la modernidad ciudadana. Son seres de los que nunca nos es dado saber - porque ellos tampoco lo saben de cierto- de dónde vienen, a dónde se dirigen, ni siquiera quiénes son en realidad. Apenas sabemos de ellos más que están ahí, atrapados en el infinito de un paisaje sólo horizonte, condenados a una situación perpetua "de paso", en un punto inestable en que un pasado borroso o borrado se cruza con un futuro incierto, que seguro que no será el de esa vida tranquila y equilibrada - un rancho, una familia- que el héroe peregrino de las películas del Oeste ansía pero que no le será dado conocer jamás. 
da a las características atomizadas y dispersas de las sociedades de frontera, cuyos exponentes han sido popularizados por las películas del Oeste en la figura del predicador a caballo que se desplaza de pueblo en pueblo o de campamento en campamento, o los festivales religiosos en carpas itinerantes que siguen el modelo de los circos y de cuyo ambiente contamos con excelentes representaciones en la película de Richard Brooks, El fuego y la palabra o la novela La Biblia de neón, de John Kennedy Toole.

En esa misma dirección, la concepción moderna de calle, tal y como se implanta en Estados Unidos, persigue idéntico fin, que no es otro que ese mismo de evitar, soslayar y, si es posible, abolir en el plano de lo sensible - que no de lo real- la existencia de complejidades, de plurales mundos y, en especial, de desigualdades y asimetrías socio-económicas, y hacerlo a través de una monotonización del espacio público. Este pasa a constituirse en un espacio en el que las gentes basan su relación en la indiferencia, la reserva y el alejamiento mutuo, una neutralidad que no es sino la consecuencia de la premisa protestante ya enunciada de que "ahí fuera" - es decir fuera de la intimidad personal o de la privacidad hogareña-, no puede haber nada realmente interesante ni de importancia. Toda vida debe ser la crónica de una defensa o/y huida de un mundo por definición peligroso y contaminante, en una pugna constante de los vivos por liberarse de las penas diarias y en una lucha desesperada - y condenada de antemano al fracaso- por conseguir un autocontrol absoluto. En todos esos frentes, el único instrumento que le es concedido al nuevo ciudadano moderno es el sentimiento religioso, que puede producir la sensación de que es posible negar la realidad externa, disiparla, hacer como si no estuviese ahí. Es preciso reconocer hasta qué punto es deudor de la cosmovisión protestante el lenguaje que describe el espacio urbano como alienante, impersonal, excluyente, frío, inhumano, etc. ${ }^{32}$

32 Un trabajo reciente de dos jóvenes antropólogos urbanos ha analizado el proceso de difusión geográfica de las congregaciones pentecostales en Barcelona, abundando todavía más en esa conceptualización de la difusión sectaria en términos de evangelización-civilización de territorios ignotos y fronterizos, habitados por infieles sin Dios. Las lógicas expansivas protestantes se revelan como impredecibles y sometidas a una combinatoria de interconexiones casi arbitrarias y cambios aleatorios en extremo, como corresponde al propio contexto socio-espacial metropolitano - por tanto liminal y heterogéneo- Es más, la indagación geo-histórica pone en seguida de manifiesto cómo la expansión urbana va acompañada sistemáticamente de una expansión de los locales de culto. El resultado es un movimiento de base policentrada que al expandirse confiere a su cartografía un carácter abigarrado y caótico de implantación y difusión. Ello lleva a los autores del trabajo a describir las dinámicas expansivas de los cultos pentecostales como la labor de "colonos-misioneros", predi- 
Resumamos recordando que fue Max Weber quien notó por primera vez cómo la mentalidad calvinista acababa propiciando una insatisfacción crónica cuyo escenario era la vida ordinaria moderna, lo que hacía de la calle un lugar infernal, a las antípodas de los beneficios interiores de la gracia, en el que cada individuo debía luchar por mantener su propia integridad. El hombre moderno era así condenado a experimentar una situación constante de malestar interno, entendido casi como una calidad inseparable y consubstancial de la experiencia de la vida ordinaria. El espacio público dejó de ser un lugar plagado de certezas y de signos que irradiaban valores y principios comunitarios, hipostatados en divinos, para devenir, de pronto, una tierra vacía de Dios, una esfera de inseguridades que era tanto más temible cuanto se suponía que era en ella donde se reflejaban las posibilidades de salvación o condenación personales, y en la que era imposible mostrarse tal y como se es en realidad. La afirmación del propio yo no podía hacerse sino por la vía de la negación y la inhibición del mundo, de tal forma que la redención y la vida eterna dependían de la capacidad humana para abominar de toda iddolatría a la criatura" $\mathrm{o}$, lo que es igual, para negar lo inmediato, lo sensible, lo concreto, en favor de un futuro mejor en otra dimensión a la que sólo los elegidos podrían acceder.

\section{MODERNIZACIÓN Y SANTIDAD DE LOS CORAZONES}

Cabría preguntarse si los nuevos cultos e incluso un buen número de adscripciones militantes laicas actuales no son sino prolongaciones, con toques más o menos exóticos y sincréticos, de ese mismo principio de autocontrol y de ascetismo intramundano que se acaba de describir, que atienden idéntica demanda de autorregulación basada en la contracción a la experiencia íntima y en la negación de lo sensible. Plantear los nuevos cultos religiosos como variantes actualizadas, renovadas por la vía de la síntesis o de la exotización, de la lógica del mundo propia del ascetismo puritano exige evocar el tipo de religiosidad que encontró en Estados Unidos no tanto su cuna, como su lugar de máximo apogeo y desarrollo. Varios son los ingredientes que confluyeron a la hora de crear formas prácticas y organizativas de religiosidad específicamente adaptadas a las

cadores que trabajan la palabra y que difunden su verdad por polinización. Cf. David IGLESIAS, "El asentamiento protestante en Barcelona", y Josep Anton SÁNCHEZ DE JuAN, "Les estratègies de localització de les esglésies evangèliques. L'exemple de les Assamblees de Germans a Barcelona", H. Capel (ed.), Habitatge, especialització $i$ conflicte a la societat catalana (Tàrrega: Ajuntament de Tàrrega, 1996), pp. 109-128. 
necesidades del proceso de modernización en aquella nación, todos asociados a lo que Ernest Troeltsch había llamado los «hijastros del protestantismo", es decir, las tendencias sectantes del anabaptismo, las variantes más heterodoxas del anglicanismo y del luteranismo y un "calvinismo radicalizado pietísticamente, ${ }^{33}$.

El primero y básico de esos ingredientes de base es sin duda el calvinismo presbiteriano, sobre todo por lo que hace a su antisacramentalismo radical y a la premisa fundamental de que el ser humano debe ser considerado en la soledad y la libertad de su alma, desnudo de la protección de los ritos y asumiendo el requerimiento de estructurar desde el sí mismo la propia vida moral. Desde las revoluciones puritanas, la religión pasaba a identificarse con la ética personal en un doble sentido: como una moralidad práctica y normativa, desde la que se regula el comportamiento del individuo respecto del grupo y las instituciones sociales, y como una ética de la intimidad en la relación con lo trascendente. Al lado de estos elementos asociados al individuo, el puritanismo incorporaba una importante dimensión colectiva. Si bien la raíz de la religión se hundía en la soledad del alma, el sentido profético de todo el cristianismo requería que la acción trascendiera lo individual y apuntara al orden histórico para cumplir sus postulados éticos mediante una "comunidad de los justos". Esa comunidad santa, la holy community, debía combatir el mal social, imponer una moralidad en las relaciones humanas y condenar a los recalcitrantes al ostracismo y el rechazo. A partir de tal doctrina se desprende un valor ético-social básico, cual es la distribución de los individuos sociales en dos categorías incompatibles - los elegidos y los réprobos-, basadas no tanto en las conductas objetivables sino en un fundamento absoluto, irracional e incomunicable, en la medida que tenía su origen en una experiencia mística personal.

Esto último está asociado a otro componente fundamental en la sentimentalidad religiosa actual y sus consecuencias organizativas, y que es la ya aludida fuerte tendencia sectante del anabaptismo - de la que resultarían bautistas, mennonitas, cuáqueros, etc.- De hecho el contraste canónico entre iglesia y secta de Weber y Troeltsch parte de esa noción de secta como comunidad que - a diferencia de la iglesia - ya no engloba a justos e injustos, sino sólo a los primeros. La secta es entonces una congregación a la que sólo pueden pertenecer personas realmente creyentes y regeneradas. A la comunidad de santos - en el sentido etimológico de separados - que es la secta sólo pueden integrarse quie-

33 Ernst Troeltsch, El protestantismo y el mundo moderno (México: FCE, 1958), p. 68. 
nes han sido llamados personalmente por Dios, de lo que se derivan todo tipo de escrúpulos a la hora de comunicarse con el mundo de los no elegidos, todo él constituido por quienes no han recibido el soplo interior del Espíritu y han sido por tanto condenados.

A su vez la expansión del denominacionismo moderno está directamente relacionada con la consideración de la frontera como territorio de misión. Esto requiere considerar las condiciones básicas de existencia de las tendencias puritanas que protagonizaron la evangelización de los territorios espiritualmente vírgenes destinados a la colonización capitalista, en especial el papel fundamental jugado en ello por las tendencias que la comúnmente aceptada tipología de Bryan Wilson presenta como conversionistas, cuyo presupuesto es que "lo que necesitan los hombres es una experiencia del corazón, y sólo cuando hayan tenido una tal experiencia de salvación puede la sociedad esperar una mejoría ${ }^{34}$. Las denominaciones conversionistas no fueron de hecho otra cosa que una radicalización del pietismo luterano centroeuropeo, centrado en la proclamación del principio de la sola fide como vehículo de salvación, en detrimento del dogma de la predestinación de los reformados. Del pietismo el conversionismo hereda el sentimiento substancial de Dios, la búsqueda de una auténtica penetración de lo divino, la emocionalidad del acto de recibir la "gracia inmerecida del Espíritu", el rapto indescriptible ante la certituto salutis, la substitución del tono circunspecto del calvinismo por una alegría surgida de la confianza y la certeza, etc.

No obstante el conversionismo hacía compatible el ultra-individualismo pietista con una religiosidad por fuerza coral, que se traducía en un activismo de masas en todas sus variantes. Como Weber recordaba, la mística protestante no tenía nada de incompatible con un fuerte sentido realista y racionalista, precisamente por el rechazo de las doctrinas dialécticas que implicaba. Este sentimentalismo religioso, dependiente de una exaltación de las posibilidades místicas del self, del yo-mismo, era extraño al calvinismo, pero no a la vocación misionera de los movimientos conversionistas, asociada a su vez a cierta tradición del catolicismo medieval que el benedictismo representaría. La lógica sectaria implicaba, en efecto, un ascetismo que ya había encontrado su precedente en el monaquismo, sólo que ahora esa negación del mundo no se traducía en un enclaustramiento, sino en todo lo contrario: un vaciarse en la actividad secular y diaria, un estar contra pero en la sociedad y sus instituciones. No se pierda de vista que la versión romana de la devotio moderna

3.4 Bryan WiLson, Sociología de las sectas religiosas (Madrid: Guadarrama, 1979), p. 38. 
se concretó, a partir del siglo XVI, en la asunción por parte de las órdenes religiosas de tareas de recristianización de las ciudades. Fueron los jesuitas quienes hicieron suya la divisa in actione contemplativus, principio que concebía que todo lugar de acción debía ser, al mismo tiempo, lugar de contemplación.

Otro presupuesto doctrinal conversionista fue el de que no todo lo revelable por Dios había sido ya revelado —es decir que Dios no lo habia dicho todo de golpe-, y existía una perdurabilidad de la Palabra divina que trascendía el texto bíblico para actuar por medio de la fuerza del Espíritu, una fuerza que se desparramaba en la vida cotidiana de quien fuera capaz de recibirla. Weber lo había visto con claridad: «El ascetismo cristiano], cerrando tras de sí la puerta del monasterio, se lanza a la plaza pública y emprende la tarea de impregnar metódicamente de ascetismo esa misma vida cotidiana, transformándola en una vida racional en este mundo, pero $n i$ de este mundo ni para este mundo" ${ }^{35}$.

Acaso el más destacado teórico contemporáneo del conversionismo fue William James, que, por cierto, estaba convencido de la "admirable congruencia de la teología protestante con la estructura de la mente, ${ }^{36}$. James, que tan vinculado estuvo a la mind-cure, el precedente inicial de la actual cienciología, ya describió la conversión como un proceso de unificación u homogeneización de personalidades que viven con angustia la experiencia de la fragmentación ${ }^{37}$. James, desde postulados ya cercanos a las ciencias humanas, describe la conversión en términos de feed-back positivo, cuando, haciendo propia la metáfora de los equilibrios mecáni$\cos$, la define como choque emocional que expresa cambios orgánicos, que, después de hundir toda la estructura, encuentra un nuevo punto - ahora por fin permanente- de equilibrio y estabilidad. El resultado de la conversión, según James, sería la obtención de lo contrario al estado de ambigüedad: el "estado de certidumbre", pérdida de toda preocupación, bienestar, paz, armonía, ganas de vivir, a pesar de que las condiciones externas se mantengan igual. El mismo principio lo encontramos en otro gran filósofo, emparentado directamente con el pragmatismo de James:

35 Max WEBER, L'ètica protestant i l'esperit del capitalisme (Barcelon: Edicions 62/ La Caixa, 1984), p. 218. Los subrayados son suyos.

36 William JAMES, Les varietats de l'experiència religiosa (Barcelona: Edicions 62/La Caixa, 1985), p. 193.

37 "Convertirse, regenerarse, recibir gracia, experimentar la religión, adquirir una seguridad, son todas ellas frases que denotan el proceso, súbito o gradual, por el que cual un yo dividido hasta aquel momento, conscientemente equivocado, inferior o infeliz, se convierte en unificado y conscientemente feliz, superior y justo, como consecuencia de mantenerse firme en realidades religiosas". Ibidem, p. 157. 
George Santayana, que, en sus obras de pensamiento, pero también en su novela El último puritano, plantea su noción de "autotrascendencia" como el resultado de la tragedia de un espíritu que no se contenta con comprender, que pretende ordenar el mundo a partir de una elección moral que no se deriva de la razón sino de una "fe animal" y cuyo "impulso auténtico es trascender a la agitación" ${ }^{38}$. Es decir, exactamente el reverso de lo que significaría, siguiendo a Van Gennep y Turner, un estado liminal definido precisamente por la intranquilidad, el temblor, de quienes lo atraviesan.

El conversionismo es un fenómeno no exclusivo, pero sí asociable en especial al amplio movimiento de revitalización religiosa que conoció Norteamérica en la década de 1720 , como respuesta a lo que se experimentó como un proceso - tan parecido al que hoy suele considerarse erróneamente como inédito- de descristianización y laicización. Se trata de lo que se dio en llamar Great Awakening, el Gran Despertar, un magno estado de ánimo colectivo que percibió la súbita y casi violenta conversión interior como la única forma de superar el vacío espiritual que la expansión colonial estaba produciendo entre sus socialmente atomizados y moralmente desarticulados protagonistas. Los pioneros en este movimiento fueron algunos sectores presbiterianos que proclamaron que era esa profunda transformación personal, basada en un reencuentro con el evangelismo más puro, lo que permitiría organizar una conducta en la que la moral, la justicia, el amor al prójimo tuviesen prioridad sobre cualquier otra tendencia humana. Hay que apuntar, sin embargo, que estas corrientes no eran propiamente calvinistas, sino más bien antipredestinacionistas, en la medida en que le otorgaban una importancia fundamental a la participación humana en la redención del pecado. Ello sin menoscabo de conservar del calvinismo una conciencia estricta de la moralidad y un poderosísimo espíritu misionero, que no perdía de vista el papel del ministerio de la palabra de Dios. Es decir, el convencimiento de que el verbo divino es, en primera instancia, la palabra hablada y oída de la predicación cristiana, premisa que guió desde el siglo xvi la actividad de los predicadores reformistas y el estilo vehemente que emplearon en sus sermones. También hay que destacar su condición apocalíptica y milenarista — derivada a su vez del anabaptismo-, que institucionalizó la expectativa del fin de los tiempos y de la implantación inminente en la tierra del Reino de Dios.

En este contexto del apostolado de frontera, en lo que enseguida serán los Estados Unidos, irrumpe con fuerza la escisión de la iglesia anglicana

38 George SANTAYANA, La idea de Cristo en los Evangelios (Buenos Aires: Editorial Sudamericana, 1966), p. 263. 
de John Wesley, que, en 1738, había inspirado en Inglaterra una corriente ecuménica e interconfesional, el metodismo, muy influida por el pietismo de los hermanos moravos. El metodismo se basaba en el libre arbitrio y promulgaba un ultraindividualismo religioso, según el cual la gracia se obtenía por medio de una intensificación de la experiencia religiosa, llevando hasta sus últimas consecuencias el principio protestante de la salvación mediante la fe y la adquisición de una santidad personal a través de episodios de vivencia inmediata y rotunda del favor de Dios. Se trata de la llamada segunda bendición, distinta de la conversión, complemento y resultado de ésta, que es experimentada como la instantánea santidad del corazón. Por su insistencia en la predicación, el metodismo se conduce a la manera de un verdadero pietismo de masas.

A lo largo de todo el siglo XIX se produce la gran predicación metodista, en especial en el transcurso de la expansión hacia el Oeste, reuniendo gentes en movimiento, desplazados, caravanas itinerantes, poblados o campamentos provisionales y localidades débilmente estructuradas. Esas congregaciones efímeras se producían con mucha frecuencia bajo la forma de festivales religiosos, en los que no eran extrañas crisis extáticas individuales o colectivas en las que los asistentes podían entrar en trance, sufrir crisis catalépticas o espasmos, ponerse a bailar frenéticamente o aullar, etc. Esta labor de misión la llevaban a cabo predicadores aislados, al margen de toda iglesia o nominalmente vinculados al congregacionismo, al baptismo o al presbiterianismo, a pesar incluso del predestinacionismo de estos últimos. Los ámbitos predilectos para llevar a cabo la difusión de la palabra de Dios fueron siempre los caminos, los lugares de paso, los espacios de frontera, lo que era congruente con el modelo que el conversionismo adoptaba del episodio de la iluminación de San Pablo, tal y como aparece en los Hechos de los Apóstoles, que no en vano está protagonizado por un personaje en tránsito, de paso, a quien le sobreviene la transformación mística en el momento en que se encuentra en un espacio intersticial entre dos puntos del mapa.

Los metodistas supieron crear una síntesis magistral entre el puritanismo de los calvinistas, una especie de sentimentalismo universal de base quietista y un racionalismo pragmático extremo, inspirado en el pelagianismo, que sostenía que el ser humano podía conseguir la salvación por sus propios medios y que el éxito personal en cualquier campo - los negocios, por ejemplo- era señal inequívoca de haber alcanzado la salvación. El metodismo - entendido mucho más como un estilo altamente emocional de predicación y de reunión religiosa, al tiempo comunitarista e individualista, que como un culto organizado- no tardó en revelarse como la forma de religiosidad que mejor se adaptaba a las condiciones 
de inestabilidad y de incertidumbre vital que caracterizarian las situaciones de no man's land o tierra de nadie, idónea para servir de soporte moral, de esperanza y de justificación última para una multitud dispersa y desorientada como la que protagonizó los grandes éxodos colectivos que colonizaron el occidente de Norteamérica. Entre las corrientes metodistas destacó enseguida el Ejército de Salvación, fundado por William Booth, que hizo de las exhibiciones públicas uno de sus elementos fundamentales y cuya labor significó el desplazamiento que llevaría la predicación conversionista de la dispersa e inarticulada sociedad de la expansión hacia el Oeste a los barrios obreros y marginales de las grandes urbes norteamericanas.

En efecto, el tipo de predicación metodista "de frontera" demostraría enseguida su pertinencia entre las grandes masas que, desde todos los países del mundo, se desplazaron a Estados Unidos a partir de la segunda mitad del siglo xIx, para constituirse en el peonaje del macroproceso de industrialización y urbanización que habría de conocer aquel país. Las grandes ciudades se convirtieron con ello en los nuevos territorios de desestructuración y anomia sociales a colonizar. En ese marco empiezan a proliferar esas derivaciones del metodismo que fueron, primero, los milleritas y los campbelitas o discípulos y, poco después, las misiones o asambleas de Dios, a veces ecuménicas o aconfesionales, a veces cuajando en denominaciones como las que aparecen a partir de 1880: National Holiness Movement, Pentecostal Church of the Nazaren, Metropolitan Church Association, Pillar of Fire Church, etc. La popularidad del nuevo movimiento - el pentecostalismo- la propiciaron los rumores sobre actuaciones sobrenaturales, indicadores de una presencia "al pie de la letra" del Espíritu Santo: curaciones milagrosas, don de lenguas — glosolalia-, "experiencias de glorian, etc.

En todos los casos se destaca el protagonismo de las mujeres en el culto y en las tareas misioneras, muchas veces en lugares de jerarquía, demostrando la idoneidad de este tipo de movimientos para promocionar sectores sociales hasta entonces postrados. El pentecostalismo se popularizó rápidamente entre los inmigrantes, los blancos pobres y los negros. Se calcula, por ejemplo, que el $70 \%$ de la población hispana de Nueva York es pentecostalista, y un porcentaje parecido podría ser aplicable a la comunidad italiana. También se extendió en Europa, donde se popularizaría entre los antillanos o los indios occidentales inmigrados a Gran Bretaña o entre las comunidades gitanas, pero no menos entre amplios sectores de las clases medias urbanas. Desde 1966 el pentecostalismo es un movimiento aceptado por la Iglesia Católica bajo el nombre de Renovación Carismática. Las experiencias extáticas que tenían lugar tanto indi- 
vidual como colectivamente en los shows pentecostales testificaban ya no la recepción de la gracia sino la presencia literal del Espíritu Santo. Esta radicalización del conversionismo resultaba de su propia condición inerrantista - creencia en la literalidad de las Escrituras-, según la cual las manifestaciones carismáticas son expresiones de los dones conferidos a los creyentes por el Espíritu Santo, tal y como son descritos por San Pablo en la primera carta a los Corintios, que todavía estaban actuando hoy. A su vez, las manifestaciones de posesión, por su identificación con la "postrera lluvia" de la que habla el Libro de Joel y el de Santiago, como el signo que preludia la venida de Cristo, entroncaban el pentecostalismo con el clima milenarista que había difundido en Estados Unidos la publicación de los Fondamentals en 1910, a cargo de los sectores más ultraconservadores de las iglesias bautistas, episcopalianas y presbiterianas.

Debe señalarse que -desde las premisas conversionistas- esas expresiones de la presencia santificadora del Espíritu pueden expresarse en privado, pero están esencialmente destinadas por Dios a la vivencia de la comunidad, es decir han de ser preferentemente públicas, puesto que sus virtudes son - paradójicamente si se quiere- estructurantes y alimentan la articulación social ${ }^{39}$. Eso es también lo que explica la mínima preocupación del pentecostalismo por la teología, en la medida en que se trata básicamente de un culto de ejercicios de piedad comunitaria basados en la emoción, en la que los asistentes se abandonan a expresiones de afirmación de sí mismos; fórmula que resume a la perfección la cualidad de los nuevos cultos de hacer compatible el sentimiento de comunidad con la exaltación individualista.

La clave del éxito de los movimientos pentecostales entre comunidades sometidas a vertiginosos procesos de modernización ha de buscarse en ese mismo cambio en las sensibilidades religiosas a las que los grupos pentecostales se han mostrado más receptivos que el catolicismo, que las iglesias protestantes más estandarizadas o que las ideologías laicas más o menos transformadoras, ofreciendo nuevas propuestas de vivencia de la fe más afines a las demandas del individualismo de masas hegemónico.

Estas demandas quedan cubiertas por una oferta de renovación personal por parte de cultos de contenidos fuertemente emocionales, en el marco de congregaciones en las que se prodiga una atención personalizada a los fieles, en que no se escatima el recurso a ritmos y melodías populares y en las que las jerarquías han sido en gran medida disueltas en cultos extáticos, basados en la glosolalia, el "quebrantamiento en manos del Es-

39 Cf. Bryan TAYlor, "Conversion and Cognition. An Area for Empirical Study in the Microsociology of Religious Knowledge", Social Compass, XXIII, 1, pp. 5-22. 
píritu" y la instantánea santidad de los corazones, con mensajes extremadamente sencillos y el inconmovible referente escriturista.

¿Qué es lo que se ofrece a los conversos al pentecostalismo? La respuesta a esta cuestión es: a) el conocimiento de la palabra de Dios para obtener la salvación ; b) la recepción de dones divinos mediante el Espíritu Santo, dones que podían ser capacidades adivinatorias, clarividencia, facultades curativas, capacidad de hacer milagros, glosolalia o don de lenguas, etc.; c) la provisión de una explicación totalizadora del mundo y del lugar de cada cual en él, y d) la obtención de un papel social nítido dentro del grupo, de modo que todos los fieles pueden desarrollar potencialmente cualquier función al ser inexistente la jerarquía. Esto último es importante puesto que implica que los lugares rectores - ancianos, pastores, etc.- pueden ser accesibles para cualquier persona que, al margen de su preparación, pueda hacer verosímil su condición de receptor del Espíritu. Otra de las claves del éxito del pentecostalismo se halla en sus especiales características congregacionales: grupos numéricamente pequeños, fuertemente solidarios y muy participativos, que son muchas veces garantía de asistencia mutua, en el plano social, económico, psicológico, etc., y en los que se encuentran razones trascendentes para abandonar prácticas a las que se responsabiliza de la desestructuración socio-familiar, como el desorden familiar, la delincuencia, el alcoholismo, la drogadicción, las lealtades al viejo clientelismo, la violencia, etc. ${ }^{40}$ En otro plano $-\mathrm{y}$ eso explicaría el éxito pentecostal entre las clases medias asentadas-, la transfiguración personal que propicia la conversión radical se ha demostrado eficaz en orden a dotar de valor trascendente vidas ordenadas, pero experimentadas como sin sentido: "Los confusos, ricos y blancos hijos de la clase media, grupo tan desarraigado y desposeído como el que más, [que] buscaban afanosos algo nuevo que les sirviese para definir sus vidas" ${ }^{41}$.

40 Sólo a título de ejemplo de trabajos relativos a cómo opera el pentecostalismo en diferentes contextos, cf., para el filadelfismo gitano, Manuela CanTón Delgado, "Evangelismo gitano y creatividad religiosa", Antropologia, 14 (octubre 1997), pp. 4571, o Patrick Williams, "Le miracle et la nécessite: à propos du dévoleppement du pentêcostisme chez les Tsiganes", Archives de Sciences Sociales des Religions, 73 (1991), pp. 81-98. Sobre el pentecostalismo en el sur de Italia, Maria Pia DI BellA, "Langues et possession: Le cas des pentecôstistes d'Italie méridionale", Annales ESC, 4 (1988), pp. 897-890. Para Centroamérica, M. CANTÓN DelGado, "Protestantismo y violencia en tierras mayas", Antropología, 8 (1994), pp. 31-58. Por último, sobre el emblemático caso brasileño, J. GuTwirTh, "Pentecôstisme national et audio-visual à Porto Alegre (Brésil)", Archives des sciences sociales des religions, 73 (1991), pp. 99-114, y A. P. OrO, "L'argent es ses répresentations dans le pentecôstisme brésilien", C. Pétonnet y J. Gutwirth (eds.), Ferveurs Contemporaines (París: L'Harmatann, 1993), pp. 101-110.

41 Robert GReEnFIELD, El supermercado espiritual (Barcelona: Anagrama, 1979), p. 21. 
También son una fuente infalible de explicación causal. La violencia, la desestructuración son atribuidas a los muchos pecados cometidos y a largas tradiciones de idolatría y paganismo católico. La pobreza o el fracaso social son, por tanto, a partir de esa lectura causal, la consecuencia de no haber sabido o querido escuchar la voz de Dios. En cuanto a la sociedad, está afecta por un caos demoníaco, como se corresponde con la premisa protestante de la generalización y la universalización de la culpa. Los males sociales, por su parte, sólo quedarán resueltos por una revolución que no es social, ni política, puesto que no tiene lugar en el mundo, sino en el corazón de los hombres. Pero sobre todo, el gran prodigio de la conversión se habrá de producir en el campo de la distribución de posiciones en el seno de la estructura social: de pronto, los pobres, los náufragos de los procesos de modernización, las comunidades más desestructuradas, los peor asentados en el sistema social, se convierten en centro del mundo. Los desposeídos son poseídos y los marginados se revelan como los escogidos por Dios.

En resumen, las sectas protestantes de nuevo cuño irrumpieron y continúan activas en los procesos de modernización en la medida en que son capaces de proveer de un nuevo lenguaje con el que dar cuenta de la pobreza, la desorganización social, la desintegración cultural, la disolución de los viejos vínculos comunitarios, propiciando nuevos sentidos y nuevos vínculos ideológicos y emocionales, nuevas fuentes de energía para la construcción identitaria tanto personal como comunitaria. Las sectas neoprotestantes han avanzado por su flexibilidad, su atomización, su versatilidad adaptativa a esquemas sociales, estructuras locales, tradiciones históricas e ideosincracias culturales muy heterogéneas. Es más, bien podríamos decir que creencias y corrientes religiosas que podrían parecer internacionales e internacionalizantes representan fórmulas de inmixtión del todo distintas, configurándose en formas de movilización muy diferentes entre sí y con resultados sociales y políticos sin apenas conexión. Ora pueden conformarse como instrumentos de legitimación de la expansión capitalista o de regímenes políticos despóticos, ora como herramientas al servicio del establecimiento de clases medias, ora como argumento para la resignación y el conformismo de los pobres, ora para la estructuración de una conciencia emancipadora y de resistencia en grupos oprimidos, una de las pocas opciones de organización accesibles para clases sociales subalternas. 


\section{PREdiCaCión EN NO-LUGaReS}

El proceso que se acaba de describir ha sido determinante a la hora de definir los estilos formales e ideológicos de todas las variantes del sentimiento religioso actual, incluyendo a las religiones institucionales como el catolicismo o las denominaciones protestantes más estabilizadas, que están experimentando un proceso creciente de carismatización, siguiendo el modelo pentecostal. Pero debe subrayarse también cómo los cultos sectarios más recientes no han hecho sino añadir elementos de todo tipo a ese esquema que el sectarismo protestante norteamericano, derivado de la revolución conversionista, representa. A ese substrato se le han añadido distintos ingredientes, dando lugar a una heterogeneidad que ha ido creciendo en una maraña sincrética, que ha incorporado componentes exóticos y hasta extrarreligiosos y que ha puesto el acento en un aspecto u otro de la fórmula básica. Así, algunos grupos han enfatizado la relación entre salvación y éxito personal, a la manera de los modos manipulacionistas de Ciencia Cristiana, Dianética o Amway. El salvacionismo milenarista de testigos de Jehová y cristadelfianos y el revelacionismo mormón han derivado en creencias adventistas en ovnis, en las que el rescate sobrenatural ha sido sustituido por la abducción extraterrestre. Algunas tendencias pueden ser consideradas como derivaciones protestantizadas de la contracultura de los años 60, con su mezcla de orientalismo y el uso místico - pseudochamánico- de substancias alucinógenas o narcóticas, o que reclaman aspectos de la herencia hippy, como la libertad sexual, a la manera de los Niños de Dios o la Familia del Amor.

Merecen una atención especial todos los sincretismos de base védica que se originan ya a finales del siglo XIX, con la presencia de Vivekananda y la Orden y Misión Ramakrishna y, en menor grado, la más secretista Orden de la Estrella de Oriente de Krishnamurti. De ahí se deriva una larga retahila de denominaciones y cultos de look orientalizante, algunos de vocación psicoterapeútica, como Meditación Trascendental o Sri Aurobindo -este último como resultado de incorporaciones del evolucionismo místico cristiano a lo Theilard de Chardin-, o adoptando el modelo oriental de la vida monacal y del misionerismo, como sería el caso de Ananda Marga, Bhagwan Rajneesh, Misión de la Luz Divina de Maharaj Ji o Hare-Krisna. A su vez, cabe mencionar cultos nominalmente fieles al cristianismo, pero que han asumido paradigmas de convivencia carismática en torno a un líder místico, tomados de la figura de los gurús o los darsham orientales, como Vida Universal o la Asociación para la Unificación del Cristianismo Mundial - los seguidores de 
Moon-, este último explicitando su adscripción a un pentecostalismo orientalizado ${ }^{42}$.

Pero todas estas corrientes, repitámoslo, no serían sino actualizaciones exotizantes, puestas al día en clave sincretista, de esa misma mecánica de rechazo del mundo, de esa misma voluntad desesperada de expiación y salvación, de idéntico autorrepliegue en la vivencia privada de la fe y de acuartelamiento en comunidades muy pequeñas, en que se ha revelado posible aquella sociedad pura y justa donde las personas pueden realizar una autenticidad que es a un mismo tiempo natural y espiritual. Esta pequeña comunidad sectaria es la que Victor Turner identificaba con la communitas liminal, pero que no era, como veíamos, sino la unidad social pre-urbana a la que las ciencias sociales han venido a denominar Gemeinschaft o 'comunidad", solidaridad mecánica o sociedad folk. Su misión: realizar la tarea moral y psicológica que la familia nuclear cerrada -el "hogar", concebido a la manera de nido- había recibido el encargo civilizatorio de llevar a cabo, que fue la de constituirse en refugio en el que los seres humanos pudieran vivir su verdad, al margen o mejor dicho contra una vida pública vista como artificial, inhumana, desalmada, desestructurada y pecaminosa. Respecto a esa labor, la unidad doméstica moderna ha fracasado, y es lo que justificará la aparición de cultos que no sólo brindan un lugar de reunión dominical para comunidades física o moralmente desarticuladas, sino la propia viabilidad de una colectividad basada en la verdad y la franqueza. Ese ámbito de protección hace lo que la familia debería haber hecho pero no ha sabido o no ha podido hacer, que no es otra cosa que dotar a los individuos de un referente ético y normativo sólido: una estructura capaz de dotar de significado y valor la experiencia del mundo.

De todos los grupos que han ampliado el repertorio de modelos de culto y creencia que se han ido sobreponiendo al substrato del conversionismo protestante, algunos continúan reconociendo el espacio sin territorio - la calle, como otrora fuera el Oeste americano, como hoy lo son los restos de las sociedades exóticas y por modernizar- como tierra de misión. Saben que - literalmente casi- predican en el desierto, pero eso no les desalienta puesto que saben que su público, aquel del que podrían obtener conversiones, está constituido por transeúntes, es decir por seres -ellos sí- liminales, protagonistas de esa communitas generalizada que es la actividad en la calle, en las estaciones, en los vestibulos, en

42 Cf. "Pentecostés de la unificación", discurso del Coronel Bo Hi Pak en el Manhattan Center, en 1984, citado por Pepe Rodríguez, La conspiración Moon (Barcelona: Ediciones B, 1988), pp. 414-424. 
los mercados, en los umbrales urbanos en general. Si las diferentes corrientes pentecostalistas han conseguido extenderse mediante un apostolado boca a boca, en que los vínculos familiares, étnicos y vecinales de los convertidos juegan el papel fundamental, por ejemplo; otros cultos han perseverado en la consideración de las calles y plazas como territorios por evangelizar, continentes asilvestrados cuyos habitantes, emparentados con los salvajes sin Dios de antaño, esperan la revelación que les otorgue la luz y el sentido, en este caso una fórmula para orientarse en el laberinto de la modernidad. En su excelente manual introductorio a los movimientos religiosos actuales, Alberto Cardín reflejaba esa creciente omnipresencia de los nuevos cultos como destellos de verdad que buscan atraer a los anónimos usuarios de la vía pública:

Los habitantes de las grandes ciudades europeas han acabado aceptando como un hecho corriente, a lo largo de los últimos diez años, algo que hasta entonces era poco habitual para ellos: verse abordados en plena calle por propagandistas religiosos que intentan, mediante interpelación insistente, con folletos e incluso con vistosos shows callejeros, atraer su atención hacia formas de religiosidad ajenas a su idea tradicional de lo religioso. Estos contactos personales y la profusión de carteles que, desde las vallas o las paredes del metro, convocan al viandante a reuniones de nombres estrambóticos, donde se prometen no menos estrambóticas enseñanzas, han acabado por familiarizar al ciudadano medio europeo con una serie de corrientes y grupos religiosos hasta hace poco para él desconocidos ${ }^{43}$.

En las ciudades europeas resultan parte del paisaje urbano las parejas de jóvenes postulantes de la Iglesia de Jesucristo de los Santos de los Últimos Días, los mormones, una secta sincrética adventista-conversionista, cuyo uniforme - camisa blanca y corbata, pelo muy corto, mochila a la espalda - los hace fácilmente reconocibles y que tienen la tarea misionera en espacios públicos como un servicio obligatorio a costa de sus familias, que deben cumplir si quieren ser aceptados en la comunidad de los salvados. Los testigos de Jehová - una denominación milenarista con rasgos típicamente conversionistas- a la hora de ejercer lo que ellos llaman "el ministerio de campo", alternan el puerta a puerta con la postulación en espacios dinámicos e inestables, en una tarea que no busca tanto conversiones - de hecho los llamados a salvarse cada vez son menos y más inencontrables- como el testimonio de su sola presencia, lo que ellos llaman "predicación indirecta" y que se lleva a cabo por medio de la simple visibilización - parejas con biblias en la mano y exhibición de revis-

43 Alberto CARDín, "Movimientos religiosos modernos", Contra el catolicismo (Barcelona: Muchnik, 1997), p. 172. 
tas ${ }^{44}$. Otras muchas sectas practican el proselitismo o la mendicidad como estrategias de visibilización en la calle: Moon, Niños de Dios, Cienciología, Hermanitas del Cordero, Hare Krisna, etc., pero también lo han usado iglesias protestantes "respetables", es decir no por fuerza marginales o estigmatizadas. A mediados de los años 70, una autodenominada Cruzada Internacional por Cristo -un movimiento ecuménico conformado preferentemente por evangélicos y bautistas - se hizo presente en las dalles de Barcelona y de otras ciudades de países de mayoría católica. En todos los casos parece que la autoafirmación pública mediante el callejeo tiene más importancia que los escasos —o más bien nulos- logros obtenidos mediante la predicación en la calle ${ }^{45}$.

La premisa práctica en todos los casos era que ese sujeto desconocido al que se interpelaba podía hallarse en una situación de intersticialidad no sólo circunstancial, como corresponde a alguién que "ya ha salido" de un lugar en la estructura, pero "todavía no ha llegado" a aquel otro lugar que le aguarda. Podría ser que el "tipo" al que se abordara hubiera quedado atrapado, como flotando en ese no-lugar o entre-deux, vacío no sólo espacial sino también existencial, decepcionado, sediento de absoluto, insatisfecho que "ya lo ha probado todo", desocializado al que ofrecer los productos que el vendedor de salvación trae para él: resocialización, estructuración identitaria, trascendencia, una remitologización que rescate la vida cotidiana de la insignificancia, una "vuelta a casa" en forma de una comunidad apoyada en vínculos elementales y en un proyecto de redención compartido por quienes en ella se integran, un nuevo pueblo elegido al que incorporarse. La función final: rescatar transeuntes, salvar a esos nuevos "pieles rojas", nuevos salvajes que viven la no menos renova-

44 Cf. Joan Manuel García Jorba, "Testimonis de Jehovà", Arxiu d'Etnografia de Catalunya, 8 (1990-91), pp. 49-73. Cf. también Quirinus J. MunTERS, "Reclutement et candidats en puissance", Social Compass, XXIV, 1 (1977), pp. 59-69.

45 Un grupo de trabajo del seminario Moviments religiosos urbans, que mantienen conjuntamente el Institut Català d'Antropologia y el Centre de Cultura Contemporània de Barcelona, trabajó en el seguimiento de este tipo de apostolado peripatético por las calles de Barcelona. El equipo siguió los desplazamientos por las calles de miembros de la Iglesia de la Cienciología, de las Hermanitas del Cordero y de la Federación de Familias por la Paz y la Unificación del Mundo, poniendo de manifiesto la manera cómo obedecían a reglas topográficas determinadas, se fijaban en ciertos puntos de la trama urbana y prestaban atención apostólica a personas preferiblemente solas, a las que cabía intuir como exponentes en el plano moral de la crónica liminalidad - no tener donde agarrarse - del hombre moderno. Cf. I. COMPTE, R. LLORENS y B. MAROTO, Estratègies d'apostolat a l'espai públic: Una passejada per Barcelona (Barcelona: Departament d'Antropologia Social, Universitat de Barcelona, 1998), inédito. 
da primitividad urbanícola a la que se refiriera Spengler, y que hace del habitante de las ciudades un "nómada espiritual.

Las prácticas de proselitismo en espacios públicos han sido subrayadas por quienes han contribuido a construir las figuraciones relativas a las "sectas destructivas", precisamente para advertir sobre su extrema peligrosidad, mostrándolas como formadas por auténticos depredadores callejeros, a la búsqueda de presas sobre las que abatirse y metafóricamente devorar — "comerles el cerebro", se dice-. Una de las más conspícuas representantes de la nuevas formas de mentalidad persecutoria, Pilar Salarrullana insiste en este tipo de apreciaciones : "Ya he dicho que explotan la soledad de las personas; por eso son buenos los lugares de captación de aquéllos donde la soledad es más patente: estaciones de trenes, de autobuses, aeropuertos, parques" ${ }^{46}$. En esa misma dirección, Alain Woodrow escribe:

Lo cierto es que los teams de jóvenes misioneros moonistas llevan a cabo su trabajo de reclutamiento en las ciudad, en los campus, a la salida de los templos, según una técnica probada, y eficaz. En la primera fase de "contacto", según el Manual de reclutamiento de la AUCM, hay que saber elegir el blanco: "Es preciso ser psicólogo, aprender a leer en el rostron. Después, cuando se entable la conversación, "tenemos que impresionar al interlocutor con nuestra serenidad, nuestra seguridad, nuestra concentración". Se hace necesaria la autosugestión: "Para conmover a los demás, debemos conmovernos nosotros mismos. Debemos tener una confianza absoluta en lo que decimos: hablar con sentimientos muy inten$\operatorname{sos}^{n}{ }^{47}$.

El ejemplo de los hare-krisna es acaso el más revelador. Los krisna exotizan el principio protestante de negación de lo concreto y de lo extrínseco, que es maya, es decir ilusión, karmi o consciencia falsa, espectro que se opone a la conciencia de Krisna. La división entre el mundo material y el mundo espiritual en el sistema hare-krisna es idéntica a la división entre los conceptos de interior-sagrado vs. exterior-profano que establece la cosmovisión calvinista y que justifica la negación de la heterogeneización y la complejidad de lo mundano en favor de un repliegue hacia la vivencia íntima de la fe, malignización final de un espacio en el que no es posible establecer lugares donde lo inefable pueda ser reconocido, imposibilidad de una epifanía topológica o geográfica, ni tampoco temporal. El mundo material, la ilusión o maya, se asocia a la temporalidad, al cuerpo, a lo sucio, a la irresponsabilidad, a la promiscuidad, a la ausencia de autocontrol, a la alienación. La civilización materia-

46 Pilar Salarrullana, Las sectas (Madrid: Temas de Hoy, 1990), p. 65.

47 Alain Woodrow, Las nuevas sectas (México: FCE, 1979), p. 105. 
lista es autogratificación egoísta, ausencia de metas y modelos, inseguridad, indeterminación... Frente a ese dominio de la inestabilidad y la incerteza, la consciencia de Krisna es verdadera realidad, eternidad, conocimiento, pureza, disciplina, autodominio, referentes morales claros, seguridad, compromiso vital, espiritualidad... Todo ello posible sólo en tanto los devotos de Krisna se refugian - en un sentido casi literal- en su vida conventual, en locales urbanos debidamente protegidos del ambiente que les rodea o en granjas en que se realiza la utopía del regreso a la Gemeinschaft, el organicismo de las sociedades campesinas y tradicionales que los estudiosos pretendieron sin complejidad, simples ${ }^{48}$.

Es destacable cómo la lógica de rechazo del mundo moderno que representan los hare-krisna no es ajena a la de ese conversionismo mezclado de utopismo protestante del que representarían una variante exótica. En cierto modo encarnan un retorno a lo que vimos que eran sus fuentes: el monacalismo de la Baja Edad Media, con su mezcla de utopismo ruralizante y de entusiasmo predicador en los nuevos contextos urbanos, al que sólo se ha añadido un cierto barniz exotista que imita —o más bien parodia- el darsham oriental, al igual que mencionamos que ocurría con Ananda Marga, Alfa-Omega, Misión de la Luz Divina de MaharajJi, etc. Se contaba, sin embargo, con fuentes nativas de comunidad religiosa cerrada, organizada a la manera de la "sociedad total" de la que Goffman nos ha hablado. Este modelo había sido adoptado por numerosas corrientes protestantes radicales en Norteamérica, prácticamente desde la fundación en 1694 de una primera colonia de pietistas alemanes en Filadelfia y los posteriores ensayos de holy life a cargo de los cuáqueros, desde 1776. El introversionismo basado en la negación anacronista del mundo moderno y la proclamación de una comunidad sagrada de inmigrantes perpetuos estaba inscrita en la tendencia sectaria del protestantismo americano de origen anabaptista, como puede reconocerse, ya en el siglo xIX y hasta la actualidad, en el caso de doukhobors, shakers, rappitas, hutteritas, amanitas o mennonitas amish.

Ese proyecto de boly community puritana - que habría tenido su versión católica en las reducciones jesuitas - había conocido otra poderosa reactualización en el siglo XIX, en forma de una síntesis del socialismo utópico y de las corrientes nativistas que reclamaban un regreso a la pureza de los orígenes fundadores de los Estados Unidos. No es casual que Robert Owen fundara su New Harmony en Indiana, en 1820, en lo que había sido una colonia rappita, llamada precisamente Harmony en tanto los

48 Cf. Josep VAllverdú, "La comunitat rural Hare-Krisna: estil de vida i pràctica religiosa", Quaderns de l'TCA, 13 (1998), en prensa. 
seguidores de George Rapp se presentaban a sí mismos como harmonist. También el fourierista Etienne Cabot organizó desde mediados de la década de 1840 y desde Texas un buen número de falansterios a lo largo y ancho de Estados Unidos. Como consecuencia de la síntesis entre socialismo utópico y nativismo, entre 1880 y 1926, se extienden por todo aquel país fundaciones llamadas boliness bodies, impulsadas por la Social Gospel, un amplio movimiento ecuménico que releía la doctrina del pecado original en clave de "redención social" y que tuvo en el Christian Commonwealth, fundado en 1896 en Georgia, su logro más destacado.

Hay más. El eclecticismo religioso que no ha hecho sino intensificarse y universalizarse en las últimas décadas aparecía prefigurándose en la filosofía de uno de los autores que más determinará el devenir del pensamiento y la literatura norteamericanos del siglo xIX, Ralph Waldo Emerson, el principal exponente de la escuela trascendentalista norteamericana. Es él quien procura una miscelánea en que la base puritana -Emerson es un hombre de la Divinity School- se ve enriquecida por los mismos ingredientes que conformarán después lo que, en el último tercio de nuestro siglo, se presenta como "nuevos movimientos religiosos": neoplatonismo, misticismo teosófico, cientifismo racionalista, romanticismo, hindo-budismo y, muy especialmente, una voluntad explícita por recuperar la épica de los primeros cristianos que llegaron a Nueva Inglaterra. Su constante evocación de la Church Discipline de Thomas Hooker, escrita en 1648 como cimiento de lo que hubiera querido ser una Nueva Jerusalén en América, y su compromiso con proyectos puritano-comunistas coetáneos como Brook Farm o Fruitlands, son pruebas de la deuda con el protestantismo radical del en tantos sentidos anticipador pensamiento de Emerson.

Estos datos históricos son importantes, por cuanto nos advierten de cómo la contracultura norteamericana de los años 60 - de la que HareKrisna es un producto, no se olvide- se inspiró en esos referentes para generar el movimiento hippy y, en general, el intento por hacer de la vida en comunas casi autárquicas una alternativa a la familia nuclear cerrada. Todos los proyectos comunalistas de la contracultura beberán de esa fuente milenarista, utópica y puritana, desde experiencias tan ambiciosas como la de La Granja de Stephen Gaskin en Tennessee a expresiones tardías como El Patriarca o el neo-ruralismo ecologista actual, pasando por las comunas hippies y neoizquierdistas que proliferaron en Occidente en los años 60 y principios de los 70 . Resultado de esa emulsión entre comunitarismo utopista, orientalismo y protestantismo introversionista fue, entre otros, el movimiento Hare-Krisna, pero también, en clave explícitamente pentecostalista, corrientes como Jesus People, los "locos de 
Jesús", en Estados Unidos ${ }^{49}$. Los Jesus Freaks se mostraron igualmente preocupados por combinar la vida contemplativa con un fuerte activismo en espacios públicos, como lo demuestran las imágenes que solían deparar rezando cogidos de la mano en la calle o las pintadas con que llenaban las paredes proclamando Jesus Loves you o Jesus Saves.

Es decir, a la raíz utópica nativista - regreso a una comunidad entusiasta, cerrada y autosuficiente de elegidos-, la contracultura norteamericana de los años 60 sumó otro factor fundamental del substrato religioso local como era el conversionismo puritano; es decir, la presunción de que era precisa una modificación profunda de la interioridad personal como premisa de cualquier cambio civilizatorio. Tanto el hippismo como la Nueva Izquierda colocaron en primer término la singularidad de la experiencia de cada individuo y la urgencia de promover un cambio en las consciencias individuales, puesto que la liberación debía ser tanto psíquica como social $^{50}$. Ese introversionismo de neta base puritana - compatible precisamente por ello con un colectivismo utópico antiurbano- se tradujó en un frente común en que coincidían la sociología de Wright Mills, el neomarxismo de Marcuse, el misticismo milenarista de Norman Brown, la psicoterapia zen de Alan Wats, la psicología gestáltico-anarquista de Paul Goodman o la psicodelia de Timothy Leary ${ }^{51}$. En ese marco - que tan bien retratara Robert Greenfield en El supermercado espiritual- hace su aparición la nueva oleada de orientalismo y, en particular, la Asociación Internacional para la Conciencia de Krisna, que capta enseguida a exponentes de la nueva cultura tan representativos como Allen Ginsberg, el anfitrión personal de Swami Bhaktivedamta en su primera visita a los Estados Unidos.

49 Cf. Emile Jean PIN, "En guise d'introduction, ou comment se sauver de l'anomie et de l'aliénation: Jesus People et Catholiques Pentecostaux", Social Compass, XXI, 3 (1974), pp. 227-239.

50 Mary Douglas está entre quienes han notado el fuerte ascendente puritano de grupos como la emblemática Students for a Democratic Society norteamericana. A ello le dedica un suculento comentario en Símbolos naturales: "Los miembros de la Nueva Izquierda [...] no están dispuestos a imaginarse a sí mismos siguiendo las huellas de Wycliffe y de los reformadores protestantes" (op. cit., p. 39). De cualquier modo, el referente podía ser explícito, como lo demuestra que uno de grupos pro-hippies más activos a finales de los 60 en Estados Unidos, los diggers, adoptara el nombre de una de las corrientes milenaristas puritanas de la Inglaterra revolucionaria del siglo XVII.

51 Este factor introversionista, como diferenciador del izquierdismo contracultural norteamericano respecto del marxismo ortodoxo, aparece muy bien descrito en el capítulo "Una invasión de centauros", del ya clásico libro de Theodore RoszAK, El nacimiento de una contracultura (Kairós: Barcelona, 1973), pp. 57-98. 
¿Qué sentido tiene esa obsesión por visibilizarse, por hacerse presentes en un mundo que en teoría se aborrece, que caracterizó el contraculturalismo norteamericano tanto laico como religioso? Centrándonos de nuevo en el caso de los hare-krisna, ¿qué proclama el harinama o predicación pública en las calles, actuación itinerante basada en la entonación de mantras y la distribución de publicaciones y dulces a los transeuntes? La imagen del harinama es ya indisociable del universo de representación de la ciudad moderna, hasta tal punto forma parte, fugaz pero persistente, de su paisaje visual y sonoro. Pocos elementos más identificadores de la estética urbana que ese telón de fondo espectacular que prestan los devotos de Krisna agitándose y bailando por las calles una melodía popularizada por Georges Harrison, reuniendo en torno suyo a peatones curiosos. En Blade Runner, la emblemática película de Ridley Scott sobre la ciudad del futuro, los monjes adoradores de Shiva son parte de ese universo cerrado, claustrofóbico, de una metrópolis ya completamente heterogeneizada y caótica. Allí donde haya una ciudad, allí es seguro que encontraremos a los mendicantes de vistosas túnicas, entonando sus salmodias, danzando, llamando la atención de los viandantes, haciendo visible su existencia de comunidad diferenciada, separada, por causa de su santidad.

Sociedad religiosa absolutamente fundamentada en el exilio, puesto que la conforman individuos que han decidido "convertirse" en inmigrantes procedentes de otro universo cultural, ¿a qué remite la imagen de la prédica hare-krisna por las calles? Lo que estos desertores del espacio público hacen es volver a él para brindar el espectáculo de sí mismos y de su redención. Está claro que sus posibilidades de convertir a los peatones con quienes se cruzan es remota, como ocurre con los demás postulantes públicos de otros cultos, como han demostrado historias de vida de devotos hare-krisna, que en ningún caso habían recibido la revelación como consecuencia del encuentro casual con un harinama ${ }^{52}$. En realidad, el fin que buscan no es el de convertir a nadie, sino el de recordarse a sí mismos quiénes son y quiénes fueron. Todo lo que ellos exaltan con sus cánticos, sus danzas, su presencia, funciona como un reverso de aquella realidad a la que van a enfrentarse - liminalidad generalizada, la calle como communitas, no-lugares-, en la que se evoca la plenitud espiritual y la dicha de una vida imposible fuera de la comunidad cerrada a la que regresarán luego.

52 Cf. Joan PRAT, El estigma del extraño. Un ensayo antropológico sobre sectas religiosas (Barcelona: Ariel, 1997), 127-178; así como Josep VALLverdú, El moviment Hare Krisna a Espanya. Un estudi antropològic (Tarragona: Àrea d'Antropologia Social, Universitat Rovira i Virgili, 1997), tesis doctoral inédita. 
Los devotos de Krisna representan la duración, lo eterno, lo profundo; la calle lo efímero, lo contingente, lo hueco. Son -0 quieren parecer- una estructura social perfecta, armónica, impecable, que se exhibe arrogante, que se pavonea casi, entre el desorden. Su música se abre paso entre el ruido del tráfico y el murmullo de la multitud; sus coreografías se oponen simbólicamente a los movimientos brownianos e impredecibles de los transeúntes. Han escapado del umbral. Se han liberado de la libertad. Muestran la disciplina, la homogeneidad que no alcanzarán nunca las gentes de la calle, los viandantes anónimos, sin espíritu, indisciplinados, vacíos, desorientados... Los danzantes en honor de Krisna constituyen un proyecto, lo otro es una deriva, lo otro..., lo otro ni se sabe qué es. Frente a la alteridad generalizada, ellos representan algo verdaderamente verdadero. A salvo por fin de la anomia y de la alienación, han realizado la utopía, han conseguido levantarse sobre la heteropia que les asfixiaba y confundía hasta que vieron la luz. Nostalgia de los cristales. Sueño realizado de ser, por fin, una sola cosa.

Partiendo de una crítica de los conceptos de liminalidad y communitas propuestos por V. Turner, se estudia el habitat de los nuevos cultos, que se justifican como defensa ante el peligro de una sociedad con desiertos morales. Aparecen las nuevas liturgias mundanas recogiendo el testigo abandonado por las iglesias oficiales, las formalizaciones cualitativas del espacio que expresaban los valores culturales. El poder de Dios no es ya geográfico sino interior y la sobredeterminación de lo sagrado viene dada ahora por la presencia carismática del grupo, no por una consagración ritual objetiva. La secta como comunidad del justo se opone a la comunidad eclesial que engloba a justos y pecadores. El conversionismo y la segunda bendición como resultado se manifiestan a la manera paulina en un espacio de tránsito. A las derivaciones del pentecostalismo, por las que los desestructurados llegan a convertirse en poderosos, se unen las corrientes orientalizantes como actuaciones exotizadas y mecanismo de rechazo al mundo.

On the basis of a critique of V. Turner's concepts of liminality and communitas, the author discusses the habitat of the new cults, which their adherents justify as means of defense against the danger of a society plagued with moral holes. Fresh wordly liturgies are occupying the territory abandoned by the official churches. The power of God is no longer geographic, but within oneself. The overdetermination of the sacred emerges nowadays not from an objective ritualistic consecration, but rather from the charismatic presence of the group. The sect as a community of the just opposes the church community that comprehends sinners as well as the just. Phenomena such as Conversionism and, as a result, The Second Blessing manifest themselves like in the case of Paul: in a transit space. Pentecostalism and its derivations, by which the destructured come to make themselves powerful, are joined by orientalizing trends fond of the exotic and employed to reject the ways of the world. 